\title{
Ways to increase stress resistance of grapes in conditions of moisture deficit
}

\author{
Natalia Aleynikova*, Yevgenia Galkina, Pavel Didenko, Carina Zaripova, and Vladimir \\ Shaporenko
}

Federal State Budget Scientific Institution All-Russian National Research Institute of Viticulture and Winemaking Magarach of the RAS, 298600 Yalta, Republic of Crimea, Russian Federation

\begin{abstract}
For optimal conditions of grapevine development, a relatively uniform distribution of precipitation is needed during all phases of active plant growth. However, often there are dry periods in summer months in areas of unstable moistening. At the present time, in intensive technologies of grape cultivation, foliar treatments with agrochemicals are widely used to increase stress resistance of plants to moisture deficit with the goal to protect and increase cropping capacity and gain optimal conditions of viticultural products. Our research, carried out in the conditions of Crimea, have shown that using of the studied systems of mineral nutrition with micronutrient fertilizers of the Wuxal group in conditions of air and soil drought contributed to an increase in the average bunch weight by 17.4$51.9 \mathrm{~g}$ and an cropping capacity of grapes by $9.5-35,3 \%(1-1.5 \mathrm{t} / \mathrm{ha})$. It was experimentally proven that test treatments have led to a significant increase (by 4.7-15.5\%) in the growth of green matter of bushes and in the structure index of table grape bunch by 19.1-37.8\%. Against the background of using the studied systems of nutrition, an increase in the content of sugars and phenolic substances in the must of 'Saperavi' grape variety by $8.5 \%$ and $70.4 \%$, respectively, was observed in comparison with the control.
\end{abstract}

\section{Introduction}

According to the intergovernmental group of experts, the planet Earth experiences significant warming of the atmosphere and oceans. The concentration of greenhouse gases has increased, while stocks of snow and ice have reduced, and the sea level has raised. Each of the last three decades was characterized by higher temperature near the surface of Earth in comparison with any previous decade since $1950[1,2]$.

An increase in average daily air temperature, uneven distribution of precipitation or a long absence of rains leads to a moisture deficit - the air and soil drought. The effect of drought causes significant changes in the hormonal system of plants: the content of growthactivating hormones - auxin, cytokinin, gibberellin, phenolic growth stimulators decreases, and the level of abscisic acid and ethylene increases $[3,4]$.

\footnotetext{
${ }^{*}$ Corresponding author: plantprotection-magarach@mail.ru
} 
Insufficient moistening of the vineyard is one of the main environmental factors limiting the vegetative growth of arms, shoots and leaves of the grapevine, changing the microclimate of crown and level of illumination in the area of bushes, making berries more sensitive to the heat stress, especially with a high level of solar radiation $[5,6]$.

Water deficit, like other stressors, can limit sugar absorption and starch accumulation in the growing pollen grains, impeding the process of fertilization and fruit setting, even though leading to the loss of entire inflorescences [5, 7]. The amount of available water affects the rate of sugar accumulation and the size of grape berries, insufficient moistening leads to a decrease in plant productivity and a change in the physicochemical composition of grapes and wine.

To increase stress resistance of plants to a lack of moisture, foliar treatments with micronutrient fertilizers are widely used in plant cultivation. They can be carried out during the entire growing period, especially during stress periods of plant nutrient requirements, without interaction with the components of soil, sedimentation, adsorption on the soil surface or the risk of losses as a result of erosion [8]. In the studies of Dewdar M. and Rady $\mathrm{M}$. on determining the effect of $\mathrm{K}$ on photosynthesis and water exchange parameters of plants under drought conditions, it was found that the use of potassium micronutrient fertilizers has led to a significant decrease in the stress of plants [9].

Since viticulture is a highly profitable and intensive branch of the Crimean agroindustrial complex, which belongs to the regions of unstable moistening, the purpose of this work was to study the effect of various grapevine nutrition systems on the productivity and quality parameters of grapes against the background of moisture deficit.

\section{Study objects and methods}

Field experiments were carried out on commercial plantations of wine and table grape varieties during 2019-2020 in the soil and climatic conditions of two viticultural zones of Crimea: Mountain-valley - on widly distributed table and wine varieties 'Italia' and 'Saperavi' (Malorechenskoye branch of FSUE PJSC Massandra); south-west - on the table variety 'Cardinal' (JSC Chernomorets Agrofirm) and the wine variety 'Saperavi' (LLC Zakharyin House).

The objects of research were the micronutrient fertilizers of the Wuxal group, productivity, phytometric, uvological and quality parameters of table and wine grape varieties.

The type of research - field farmscale experiment. The area size of the variant is 2 ha. Each variant includes 45 recording bushes in triplicate. Distribution of experimental variants was provided using method of elongated working plots. Application technology truck spraying (OPV-2000). The working liquid rate of consumption was $8001 /$ ha.

The research scheme included four experimental plant nutrition systems and the control systems (systems of grape nutrition used in farming, Table 1).

Table 1. The scheme of research

\begin{tabular}{|c|c|c|c|c|}
\hline $\begin{array}{c}\text { Phenological stage of } \\
\text { grape growth }\end{array}$ & Experimental variant & $\begin{array}{c}\text { Consump } \\
\text { tion rate, } \\
1(\mathrm{~kg}) / \mathrm{ha}\end{array}$ & $\begin{array}{c}\text { Farmscale variant } \\
\text { (control) }\end{array}$ & $\begin{array}{c}\text { Cons } \\
\text { umpti } \\
\text { on } \\
\text { rate, } \\
(\mathrm{kg}) / \\
\text { ha }\end{array}$ \\
\hline \multicolumn{2}{|c|}{ Experiment 1: Malorechenskoye branch of FSUE PJSC Massandra, 'Saperavi' variety, 2019} \\
\hline 1. Before flowering & Wuxal Boron $\mathrm{pH}$ & 1,5 & Ultramag B & 1 \\
\hline 2. Berries groat-sized & Wuxal Microplant & 0,5 & Potassium humate & 2 \\
\hline 3. Berries pea-sized & Wuxal Microplant & 0,5 & Potassium humate & 2 \\
\hline
\end{tabular}




\begin{tabular}{|l|c|c|c|c|}
\hline 4. Berries touching & Wuxal Microplant & 0,8 & - & - \\
\hline 5. Beginning of ripening & Wuxal Aminocal & 2 & - & - \\
\hline \multicolumn{7}{|c|}{ Experiment 2: Malorechenskoye branch of FSUE PJSC Massandra, 'Italia' variety, 2019 } \\
\hline 1. Before flowering & Wuxal Boron pH & 1,5 & Ultramag B & 1 \\
\hline 2. Berries groat-sized & Wuxal Microplant & 0,5 & Potassium humate & 2 \\
\hline 3. Berries pea-sized & Wuxal Microplant & 0,5 & Potassium humate & 2 \\
\hline 4. Berries touching & Wuxal Microplant & 0,8 & - & - \\
\hline 5. Beginning of ripening & Wuxal Aminocal & 2 & - & - \\
\hline \multicolumn{7}{|c|}{ Experiment 3: JSC Chernomorets Agrofirm, 'Cardinal' variety, 2019 } \\
\hline 1. Before flowering & Wuxal Boron pH & 1,5 & Agris B & 1 \\
\hline 2. Berries groat-sized & Wuxal Microplant & 1,5 & Ultramag B & 1 \\
\hline 3. Berries touching & Wuxal CalciumBoron & 2,5 & Humifilin & 2 \\
\hline 4. Beginning of ripening & Wuxal Aminocal & 2 & Humifilin & 2 \\
\hline \multicolumn{7}{|c|}{ Experiment 4: LLC Zakharyin House, 'Saperavi' variety, 2020 } \\
\hline 1. Before flowering & Wuxal Boron pH & 1,5 & Agris B & 1 \\
\hline 2. After flowering & Wuxal Microplant & 0,8 & Ultramag B & 1 \\
\hline 3. Berries groat-sized & Wuxal Microplant & 1,0 & Humifilin & 2 \\
\hline 4. Berries touching & Wuxal Aminocal & 2,5 & Humifilin & 2 \\
\hline 5. Beginning of ripening & Wuxal Aminocal & 2,5 & Humifilin & 2 \\
\hline
\end{tabular}

Wuxal Boron $p H$ is an innovative micronutrient fertilizer with excellent buffer properties, neutralizes $\mathrm{pH}$ of the working solution, contributing to the rapid penetration of the active substance of pesticides into the plant, while providing plants with Boron and nutrients. The preparation contains (g / 1): $\mathrm{N}-70, \mathrm{P}_{2} \mathrm{O}_{5}-183, \mathrm{~B}-108, \mathrm{SO}_{3}-5.5, \mathrm{Cu}-0.7, \mathrm{Fe}$ - 1.4, Mn - 0.7, Zn - 0.7, Mo - 0.014 .

Wuxal Microplant is a micronutrient fertilizer with high content of a wide range of trace elements with additional effect of sticking agent and surfactant. It eliminates deficit of trace elements, leading to an increase in plant productivity. The preparation contains $(\mathrm{g} / \mathrm{l}): \mathrm{N}$ 78, $\mathrm{K}_{2} \mathrm{O}$ - 157, $\mathrm{MgO}-47, \mathrm{SO}_{3}-203, \mathrm{~B}-4.7, \mathrm{Cu}-7.9, \mathrm{Fe}-15.7, \mathrm{Mn}-23.6, \mathrm{Zn}-15.7$.

Wuxal Aminocal is a complex micronutrient fertilizer consisting of mineral nutrients and biologically active substances $(\mathrm{Ca}-202, \mathrm{Mn}-6.7, \mathrm{Zn}-6.7$, polypeptides and amino acids - 68\%), developed to eliminate and prevent calcium deficit. The composition includes $\mathrm{Mn}$ and $\mathrm{Zn}$, as well as polypeptides that promote better calcium penetration and increase plant resistance to adverse environmental factors.

During the research we used generally accepted methods used in viticulture and winemaking [10-11]. The experimental data obtained were subjected to mathematical processing by generally accepted methods of descriptive statistics using the Microsoft Excel software package. The credibility level of statistical analysis rated 0.95 (95\%).

\section{Results and discussion}

In the Mountain-valley Crimea, the weather conditions of the growing season of 2019 were mostly hot and dry. Average monthly air temperatures during the period from April to September exceeded long-time average annual parameters by $0.2-4.7^{\circ} \mathrm{C}$, with a maximum excess in June (Table 2). During the growing season, there was $32.5 \%$ less precipitation in comparison with the long-time average annual and amounted $200.8 \mathrm{~mm}$. Average monthly air temperatures in 2020 during the period from June to September also exceeded the longtime average annual data by $1.2-4.1^{\circ} \mathrm{C}$, with a maximum value in September. During the growing season, the amount of $181.1 \mathrm{~mm}$ of precipitation was recorded, which was $90.2 \%$ of the long-time average annual indicator (Table 2).

Table 2. Meteorological parameters of the grape growing season 


\begin{tabular}{|c|c|c|c|c|c|c|}
\hline \multirow{2}{*}{ PARAMETERS } & \multicolumn{6}{|c|}{ MONTHS } \\
\hline & April & May & June & July & August & September \\
\hline \multicolumn{7}{|c|}{ Alushta meteorological station } \\
\hline \multicolumn{7}{|l|}{ Air temperature, ${ }^{\circ} \mathrm{C}$} \\
\hline a) long-time average annual & 10,5 & 15,8 & 21,0 & 24,1 & 24,2 & 19,2 \\
\hline b) 2019 & 11,6 & 17,7 & 25,7 & 24,3 & 25,9 & 20,9 \\
\hline c) 2020 & 10,8 & 15,4 & 22,3 & 26,0 & 25,4 & 23,3 \\
\hline \multicolumn{7}{|l|}{ Precipitation, $\mathrm{mm}$} \\
\hline a) long-time average annual & 25,3 & 28,5 & 37,1 & 34,3 & 41,5 & 34,1 \\
\hline b) 2019 & 32,1 & 14,6 & 17,3 & 23,4 & 17,1 & 31,0 \\
\hline c) 2020 & 6,4 & 13,9 & 30,6 & 29,7 & 30,0 & 70,5 \\
\hline \multicolumn{7}{|c|}{ Sevastopol meteorological station } \\
\hline \multicolumn{7}{|l|}{ Air temperature, ${ }^{\circ} \mathbf{C}$} \\
\hline a) long-time average annual & 10,8 & 16,2 & 21,2 & 23,8 & 23,8 & 19,2 \\
\hline b) 2019 & 10,3 & 17,6 & 24,1 & 22,7 & 23,7 & 19,0 \\
\hline c) 2020 & 9,6 & 14,8 & 21,2 & 23,9 & 23,4 & 20,7 \\
\hline \multicolumn{7}{|l|}{ Precipitation, $\mathbf{m m}$} \\
\hline a) long-time average annual & 23,2 & 26,9 & 34,7 & 24,6 & 26,1 & 41,9 \\
\hline b) 2019 & 31,5 & 3,5 & 55,2 & 42,5 & 41,8 & 2,5 \\
\hline c) 2020 & 9,0 & 17,3 & 45,0 & 5,5 & 0 & 68,5 \\
\hline
\end{tabular}

In the south-western Crimea, a reliable positive deviation from the long-time average data in 2019 was registered in May $\left(1.4^{\circ} \mathrm{C}\right)$ and June $\left(2.9^{\circ} \mathrm{C}\right)$. In the period from April to September, $177 \mathrm{~mm}$ of precipitation was recorded, which corresponded to the long-time average annual indicator. The analysis of meteorological data for 2020 shows that, in general, the average daily air temperatures in the viticultural research zone were close to the long-time average annual indicators, not including April and May (lower by $1.2^{\circ} \mathrm{C}$ and 1.4 ${ }^{\circ} \mathrm{C}$, respectively), as well as September $\left(1.5^{\circ} \mathrm{C}\right.$ higher). During the active growing season of grapes, the rate of precipitation was $145.3 \mathrm{~mm}$, which was $18.1 \%$ lower than the average annual rate (Table 2).

Thus, in Crimea in 2019-2020 there was a tendency of the last decade of increasing the average daily air temperature with uneven distribution of precipitation throughout the entire growing period of grapes.

In the course of the research, the phytometric parameters of grapes were determined. They characterize growth processes and peculiarities of their passage as important criteria for the grape bush design. Treatments of table grape varieties with the studied preparations contributed to an increase in the growth of green matter of the bush in the Experiment 2 by $15.5 \%\left(320.3 \mathrm{~cm}^{3}\right)$ and in the Experiment 3 by $4.7 \%\left(87.4 \mathrm{~cm}^{3}\right.$, Table 3$)$. There was no difference in cultivation of annual grape shoots.

Table 3. The effect of the Wuxal group microfertilizers on phytometric parameters of grape bushes of table varieties

\begin{tabular}{|c|c|c|c|c|}
\hline Variant & $\begin{array}{c}\text { Average shoot } \\
\text { legth (L), cm }\end{array}$ & $\begin{array}{c}\text { Average shoot } \\
\text { diameter (D), cm }\end{array}$ & $\begin{array}{c}\text { Bush growth } \\
\text { gain (P), } \mathrm{cm}^{3}\end{array}$ & $\begin{array}{c}\text { Ripening } \\
\text { degree, } \%\end{array}$ \\
\hline \multicolumn{5}{|c|}{ Malorechenskoye branch, 'Italia' variety, 2019 } \\
\hline Control & 166,0 & 0,81 & 2064,9 & 85,5 \\
\hline Experiment 2 & 176,5 & 0,83 & 2385,2 & 84,5 \\
\hline HCP $_{05}$ & 8,6 & 0,03 & 78,5 & - \\
\hline \multicolumn{5}{|c|}{ JSC Chernomorets Agrofirm, 'Cardinal' variety, 2019 } \\
\hline Control & 195,9 & 0,91 & 1843,8 & 89,1 \\
\hline Experiment 3 & 202,2 & 0,91 & 1931,2 & 90,6 \\
\hline HCP $_{05}$ & 6,1 & 0,06 & 85,6 & - \\
\hline
\end{tabular}

Recording of the quantitative and qualitative parameters of the grape yield showed that for all the studied indicators the experimental variants were superior to the control (Table 
4). Using of experimental systems of nutrition on table grape varieties contributed to an increase in the average bunch weight by $50-51.9 \mathrm{~g}$, in the cropping capacity by $1.1-1.5 \mathrm{t} / \mathrm{ha}$ and in the concentration of sugars in the grape juice by $5-12 \mathrm{~g} / \mathrm{dm}^{3}$ in comparison with the control. Statistical and mathematical processing of the obtained data showed that a significant increase in sugar content was observed for the 'Cardinal' (7.5\%) and 'Saperavi' (8.5\%, south-west of Crimea) varieties. The increase in yield of wine grape variety 'Saperavi' in the Experiment 1 amounted $1 \mathrm{t} / \mathrm{ha}(12.8 \%)$, in the Experiment 4 it was $1.2 \mathrm{t} /$ ha $(35.3 \%$, Table 4$)$.

Table 4. The effect of the Wuxal group microfertilizers on grape productivity

\begin{tabular}{|c|c|c|c|c|c|}
\hline Variant & $\begin{array}{c}\text { Average } \\
\text { bunch } \\
\text { weight, g }\end{array}$ & $\begin{array}{c}\text { Number of } \\
\text { bunches, } \\
\text { pcs/bush }\end{array}$ & $\begin{array}{c}\text { Yield, } \\
\mathrm{kg} / \mathrm{bush}\end{array}$ & $\begin{array}{c}\text { Cropping } \\
\text { capacity, } \\
\text { t/ha }\end{array}$ & $\begin{array}{c}\text { Mass } \\
\text { concentration of } \\
\text { sugars, g/dm }\end{array}$ \\
\hline \multicolumn{7}{|c|}{ Malorechenskoye branch, 'Saperavi' variety, 2019 } \\
\hline Control & 141,8 & 27,8 & 3,9 & 7,8 & 188 \\
\hline Experiment 1 & 159,2 & 27,7 & 4,4 & 8,8 & 191 \\
\hline HCP 05 & 10,4 & 0,7 & 0,6 & - & 1,8 \\
\hline \multicolumn{7}{|c|}{ Malorechenskoye branch, 'Italia' variety, 2019 } \\
\hline Control & 372,0 & 15,6 & 5,8 & 9,3 & 157 \\
\hline Experiment 2 & 422,0 & 15,5 & 6,5 & 10,4 & 162 \\
\hline HCP 05 & 14,1 & 0,7 & 0,4 & - & 2,1 \\
\hline \multicolumn{7}{|c|}{ JSC Chernomorets Agrofirm, 'Cardinal' variety, 2019 } \\
\hline Control & 682,8 & 14,5 & 9,9 & 15,8 & 161 \\
\hline Experiment 3 & 734,7 & 14,7 & 10,8 & 17,3 & 173 \\
\hline HCP 05 & 12,1 & 0,9 & 0,5 & - & 2,4 \\
\hline \multicolumn{7}{|c|}{ LLC Zakharyin House, 'Saperavi' variety, 2020 } \\
\hline Control & 69,7 & 23,9 & 1,7 & 3,4 & 164 \\
\hline Experiment 4 & 97,3 & 23,7 & 2,3 & 4,6 & 178 \\
\hline HCP 05 & 13,5 & 0,8 & 0,4 & - & 2,9 \\
\hline
\end{tabular}

At the next stage of the work, the analysis of mechanical composition of table grape bunches was carried out. The reliable increase in the average bunch weight, observed in the experimental variants, was due to the gain in the weight of 100 berries by $20.6-26.3 \mathrm{~g}$ in comparison with the control, while there was also an increase in the index of the bunch structure by 19.1-37.8\% (Table 5).

Table 5. The effect of the Wuxal group microfertilizers on mechanical composition of a grape bunch

\begin{tabular}{|c|c|c|c|c|c|c|c|}
\hline \multirow{2}{*}{ Variant } & \multicolumn{7}{|c|}{ Bunch structure } \\
\cline { 2 - 8 } & $\begin{array}{c}\text { Bunch } \\
\text { weight } \\
\mathrm{g}\end{array}$ & $\begin{array}{c}\text { Number of } \\
\text { berries in the } \\
\text { bunch, pcs }\end{array}$ & $\begin{array}{c}\text { Weight of } \\
100 \\
\text { berries, g }\end{array}$ & $\begin{array}{c}\text { Stem } \\
\text { weight } \\
\text { g }\end{array}$ & $\begin{array}{c}\% \\
\text { of } \\
\text { berries }\end{array}$ & $\begin{array}{c}\% \\
\text { of } \\
\text { stem }\end{array}$ & $\begin{array}{c}\text { Structure } \\
\text { parameter, } \\
\%\end{array}$ \\
\hline Malorechenskoye branch, 'Italia' variety, 2019 \\
\hline Control & 372,0 & 75,9 & 524,7 & 7,7 & 97,9 & 2,1 & 46,6 \\
\hline Experiment 2 & 422,0 & 78,6 & 545,3 & 6,2 & 98,5 & 1,5 & 65,7 \\
\hline $\mathrm{HCP}_{05}$ & 14,1 & 2,6 & 13,7 & 1,3 & - & - & - \\
\hline \multicolumn{7}{|c|}{ JSC Chernomorets Agrofirm, 'Cardinal' variety, 2019 } \\
\hline Control & 682,8 & 71 & 738,9 & 13,7 & 97,8 & 2,2 & 44,5 \\
\hline Experiment 3 & 734,7 & 74 & 765,2 & 9,1 & 98,8 & 1,2 & 82,3 \\
\hline HCP 05 & 12,1 & 2,8 & 9,4 & 2,7 & - & - & - \\
\hline
\end{tabular}

The processing of dark-berry wine grape variety 'Saperavi' with the studied preparations of the Wuxal group provides a statistically significant increase in the mass concentration of sugars in the grape must by $14 \mathrm{~g} / \mathrm{dm}^{3}(8.5 \%$, Table 6$)$. The increase in the content of phenolic substances in the experimental sample using the studied grape nutrition 
system consisted of $169 \mathrm{mg} / \mathrm{dm}^{3}$ or $70.4 \%$ in comparison with the control. The rest of the determined parameters was at the control level.

Table 6. Physicochemical parameters of the must of wine grape variety 'Saperavi' (LLC Zakharyin House)

\begin{tabular}{|c|c|c|c|c|c|}
\hline \multirow{2}{*}{ Variant } & \multicolumn{2}{|c|}{ Mass concentration, $\mathrm{g} / \mathrm{dm}^{3}$} & \multirow{2}{*}{$\mathrm{pH}$} & $\begin{array}{c}\text { MPhMO } \\
\text { activity, } \\
\text { units* } 10^{3} / \mathrm{cm}^{3}\end{array}$ & $\begin{array}{c}\text { Total content of } \\
\text { phenolic substances in } \\
\text { the must, } \mathrm{mg} / \mathrm{dm}^{3}\end{array}$ \\
\hline Control & 164 & 12,3 & 3,0 & 0,26 & 240 \\
\hline Experiment & 178 & 11,7 & 3,1 & 0,3 & 409 \\
\hline $\mathrm{HCP}_{05}$ & 2,9 & 5,48 & 1,39 & 0,13 & - \\
\hline
\end{tabular}

\section{Conclusion}

As a result of the studies carried out in conditions of moisture deficit and showing the positive effect of the studied systems of nutrition with micronutrient fertilizers of the Wuxal group on the productivity and quality of grapes in Crimea, it was established the following:

- a significant increase in the growth of bushes of table grape variety 'Italia' by $15.5 \%$ $\left(320.3 \mathrm{~cm}^{3}\right)$ and 'Cardinal' by $4.7 \%\left(87.4 \mathrm{~cm}^{3}\right)$, in after years this tendency can have a positive effect on the productivity of grapes;

- a significant increase in the weight of 100 berries and the parameter of bunch structure of table grape varieties 'Italia' and 'Cardinal' by $20.6 \mathrm{~g}, 26.3 \mathrm{~g}$ and by $19.1 \%, 37.8 \%$, respectively, in comparison with controls;

- for all experimental variants, a significant increase in the cropping capacity of grapes was achieved: for table varieties $-9.5-11.8 \%$; for wine varieties $-12.8-35.3 \%$, due to a reliable increase in the average bunch weight by 50-51.9 $\mathrm{g}$ and 17.4-27.6 g, respectively;

- positive effect of the studied microfertilizers on the grape yield quality of varieties 'Cardinal' and 'Saperavi' (south-west zone): the increase in the concentration of sugars in the juice of berries relative to the control was $12 \mathrm{~g} / \mathrm{dm}^{3}(7.5 \%)$ and $14 \mathrm{~g} / \mathrm{dm}^{3}(8.5 \%)$, respectively; the increase in the concentration of phenolic substances in the grape must of 'Saperavi' grape variety reached $70.4 \%\left(169 \mathrm{mg} / \mathrm{dm}^{3}\right)$.

\section{References}

1. A.S. Monin, D.M. Sonechkin, Observed climate fluctuations: triple solar and other cycles, 191 (2005)

2. V.S. Petrov, G.Y. Aleynikova, L.Y. Novikova, L.G. Naumiva, Fruit growing and of the South of Russia, 57(3), 29 (2019)

3. S. Tombesi, T. Frioni, S. Poni, A. Palliotti, Environmental and Experimental Botany, 150, 106 (2018)

4. S.M. Zargar, P. Nagar, R. Deshmukh, M. Nazir, A.A. Wani, K.Z. Masoodi, G.K. Agrawal, R. Rakwal, Journal of Proteomics, 169, 233 (2017)

5. P. Baeza, P. Junguera, E. Peiro, J.R. Lissarrague, D. Uriarte, M. Vilanova, Advances in grape and wine biotechnology, 1 (2019)

6. M. Vilanova, J.M. Rodriguez-Nogales, J. Vila-Crespo, J. Yuste, Grape and wine research, 25(1), 83 (2019)

7. V. Fernandez, P.H. Brown, Front plant Sci., 4, 289 (2013)

8. K. Fort, J. Fraga, D. Grossi, M.A. Walker, Journal of the American Society for Horticultural Science, 142(1), 36 (2017) 
9. M. Dewdar, M. Rady, African Juurnal of Agricultural Research, 8(19), 2211 (2013)

10. V.G. Sychev, O.A. Shapoval, I.P. Mozharova et al, Guidelines for the registration tests of agrochemicals in agriculture: production and practical edition, 248 (2018)

11. Office international de la vigne et du vin, Compendium of international methods of wine and must analysis (2017) 